\title{
The Implementation of Good Governance with a View to Improving the Competence of State Civil Apparatus in the Regional Government
}

\author{
Rahmat Salam \\ Universitas Muhammadiyah Jakarta, Indonesias \\ rahmat.salam@umj.ac.id
}

\begin{abstract}
For more than twenty years, reforms that have been going on have mandated the existence of autonomy and decentralization of government to manage their areas and give the broadest possible power to self-determination. The granting of this authority is intended to improve. As one indicator to measure regional autonomy's success, the government will better serve its citizens and guide them towards a better life. The provincial government's performance has not matched the expectations, yet it has not done the community optimally. Increasing the competence of the apparatus to improve the quality of work is a determining factor in local government activities' success. The result of local government officials towards quality performance leads to the development of education, competence, and abilities because of the times' face. The competence that local government officials are expected to have is analyzing and addressing issues within the city under a realistic framework of local government.
\end{abstract}

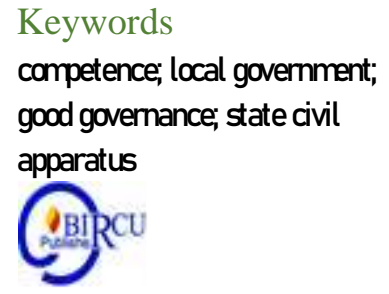

Keywords good governance; state civil apparatus

\section{Introduction}

The ongoing reforms have given color and influence to the development of public administration, namely to reinstate the government apparatus's functions as public servants (public servants (Dwiyanto, 2021; Minardi, 2019; Mariana, 2006). development, including governance and regional development aimed at providing services to the community (Rosdiana, 2019; Wahid, 2017; Dwimawanti, 2004). Thus, achieving governance and development goals must be accompanied by an increase in public service management's performance. In the context of regional autonomy, the concept of Performance measurement is one measure of local government officials' ability to carry out their authority (Oja, 2017; Wibowo \& Handayani, 2017).

The implementation of regional government has been formulated in Law No. 5 of 1974 and later amended into Law No. 22 of 1999, which has been amended back to Law No. 32 of 2004 concerning Regional government that in theory grants the autonomous territories total authority to administer and control their households in accordance with the ideals of decentralization, deconcentration and support tasks. The primary goal is to strengthen the health of the society by undertaking development programs in line with the will and desires of the organisation (Moonti, 2019; Holtzappel \& Ramst, 2009). In connection with the nature of regional autonomy, it also regards the delegation of authority for policy decision-making, public funds management, government administration activities, and community services (Tahir, 2014; Kusuma, 2016). 
Thus it can be perceived into several very essential things that local governments should adopt a community interest-oriented paradigm (customer-driven) in providing services to the broader community, preparing all instruments to fulfill this paradigm systemically (since input-process-output- the results/impact), to realize quality public services (which are tangible, reliable, responsive, safe, and full of empathy in their implementation) (Needham, 2006; Balachandran, 2004). For this reason, strict, straightforward, and adaptive rules of the game are needed to the demands of environmental development, whose characteristics are always changing rapidly and sometimes full of uncertainty. Herein lies the 'art and science of service' that the government and all levels of society must develop; there must be integration between all development stakeholders (Muliawaty \& Hendryawan, 2020; Rahmadana et al., 2020).

The problem currently facing the government is the limited quality of local government officials; this is a phenomenon that is also a significant problem encountered in the implementation of regional government in Indonesia (Saputra \& Kurniawansyah, 2020; Komara, 2019). As the spearhead of national development, the local government is required to change the vision, mission, and strategy, which is tailored to the needs of the community. Local governments are increasingly being demanded to formulate regional regulations, plan regional development that is adapted to the situation and conditions, and provide excellent service to the community. Angelia et al (2020) stated that the empowerment of village community institutions has a very strategic position and the most important part in the realization of development ideals. This then makes it important to know empowerment to the involvement of village community organizations as village government partners in assisting the performance of the Village Government to achieve development goals in the village.

On the other hand, it is also demanded to create conditions conducive to the growth and development of community creativity and innovation in managing and exploring the existing potential to bring economic added value to the community (Haris, 2005; Sumarsono, 2009). The performance of local government officials has not been as expected. Local government officials' performance is not yet optimal in carrying out their duties and functions; it is shown that the community still submits many complaints regarding the services provided by the local government so far (Rohayatin et al., 2017).

One measure of the success of the implementation of regional autonomy is that the provincial government is increasingly capable of providing services to the community and bringing the community's conditions towards a better life. However, the reality that occurs in the era of autonomy and decentralization, which is loaded with democratic values and transparency, often presents complex problems in the regions. In this era, the political process seemed faster than managing autonomous regional government management (Sutrisna, 2020).

In order to solve this issue, local government officials' competitive success with superior efficiency is necessary. The success of local authorities, which are based on consistency, needs more learning and experience following developments (Mustafid, 2017). A person will be able to take action if there is the power to exert and move his power. According to McClelland, a person's ability is a necessity learned from people's culture and obtained through education and training (McClelland, 1973). Furthermore, Sternberg \& Kaufman argued that ability is one of the elements in maturity related to knowledge and skills obtained from education, training, and experience (Sternberg \& Kaufman, 1998). 


\section{Research Methods}

The type of research used in the article on improving local government officials' competence to achieve good governance is a qualitative approach. Qualitative research is research that uses many methods, interpretive and naturalistic techniques, observes objects in a natural setting, tries to interpret or interpret phenomena from the perspective of the community, this includes the use of multiple empirical resources including case analysis, personal encounters, introspection, tales of life and interviews. Historical, interactional and visual texts, insights may define routine moments and difficulties in the life of a person (Denzin \& Lincoln, 1998).

According to Creswell: "qualitative research is a method for exploring and understanding the meaning that several individuals or a group of people think comes from a social or human problem." The problem that the researcher will study is social and dynamic. Thus the researcher opted in order to classify, capture, store, and interpret the analysis data by using qualitative methods (Creswell, 2010).

In collecting data related to research, the writer uses literature studies from sources such as books, journals, and writings related to the object under study. The literature study method involves collecting library data, reading and taking notes, and managing research materials. Each researcher carries out a literature study to find a basis for obtaining and building a theoretical basis, a frame of mind, and determining provisional estimates or known as research hypotheses. Researchers can group, allocate, organize, and use a variety of libraries in their fields. By conducting a literature study, researchers have a broader and more in-depth understanding of the problem to be researched (Darmalaksana, 2020).

\section{Results and Discussion}

\subsection{Competence of Local Government State Civil Apparatus}

The bureaucratic apparatus's ability is the supporting pillar of the bureaucratic building in the administration of government. For this reason, it is necessary to take steps to develop an acquisition orientation or qualification related to the required competencies so that the bureaucratic apparatus can play an optimal role in government administration. The bureaucracy itself is defined as running the government by people who rule professionally; this is the essence of bureaucracy (Von Mises \& Morris, 1944).

The competence of Woodruffe (1993) says: "...is the understanding of, the skills and the abilities or the abilities of an individual that belongs to the individual to the degree that he or she is able to execute in a satisfactory manner those cognitive, affective and psychanistic abilities. Competency is described, in this case, as information, skills and abilities regulated by someone whose cognitive, affective and psychomotor actions are as much as possible as possible.

More broadly than the above opinion, Hoffman (1999) states, "A competency is composed of skill, knowledge, and attitude, but in particular the consistent applications of those skill, knowledge, and attitude to the standard of performance required in employment." In other words, ability includes expertise, skills and attitudes, but it is important that the skills, skills and attitudes required are implemented at work.

From various scientific disciplines and researchers, they provide definitions of competence with different language expressions, but the meanings contained in these expressions are essentially the same. Competence is a person's characteristics relating to one's functions, roles, tasks, skills, abilities, or personal factors, which underlie a person to demonstrate a good work performance in a particular field of work, position, and situation. 
The development of bureaucratic apparatus resources is an integral part of increasing the bureaucratic apparatus's qualifications following the community's demands. Setiyono (2012) has emphasized the importance of fostering the bureaucratic apparatus's quality that is considered to hold a central position in bureaucratic organizations. The development of bureaucratic apparatus resources includes qualifications, skills, number, ability to carry out tasks, and years of service. In line with the above, Sriwidodo \& Haryanto (2010) stated that an individual's capacity in carrying out his job duties is based on intellectual and physical abilities (intellectual and physical skills).

In this regard, it is necessary to underline the importance of obtaining or qualifying bureaucratic apparatus resources concerning professionalism, experience, specialization, and capability in the alternative selection and handling of policy information. Furthermore, it also offers a concept known as an alternative concept of technocracy. This concept refers to professional orientation and expertise references. In more detail, matters that refer to the need for bureaucratic analysts who can help prepare policy information processing are disclosed. He also added that the bureaucracy that is a professional, expert, and specialist, its performance is always marked by capabilities in review analysis, cross-impact analysis, and translation of values.

The view of Perry \& Rainey (1988) discusses the need for human resource (apparatus) capacity to sustain a democratic and politically accountable government management process that complements the technical gains that must be held by bearers of the mandate of public responsibility. First of all, the achievements are the ability to image mentalistic things (mental construct/image) that need to be operationalized in the form of an elaborate moralist display that can guide official actions in public responsibility (public responsibility). The recommendation concept is then referred to as intern organizational concern installed in a normative column that can later guide the apparatus's responsive actions. This concept is closely related to professional ethics (professional ethics), which is used to suggest appropriate measures for fulfilling the dharma of government by bureaucrats, from now on referred to as the professional ethics code for a modern public bureaucratic institutional entity.

The findings of the diagnostic analysis of the Department of Home Affairs (2002) found that there are symptoms related to the handling of moral problems, behavior, and professionalism of the bureaucratic apparatus, as follows:

1. In reality, the regional government apparatus's resources consisting of the provincial civil service corps, do not yet have socio-political maturity.

2. The resources of the regional government apparatus do not have adequate experience and are less professional and far from satisfactory to handle regional autonomy issues

3. Regional government officials have not been able to position themselves as non-partisan and tend to be co-opted by specific political forces.

According to Fitzpatrick (1994), five aspects shape competences: motivations, attributes, self-conceptions, abilities and skills. Motifs and character are core skills or core skills while comprehension and skills are referred to as individual abilities that promote knowledge and ability..

In contrast to Fitzpatrick's conception, Sandberg (2000) reveals that a person's competence is closely related to their intelligence. The talents of an individual can then be divided into two: personal ability and social skill. Self-awareness, self-regulation and inspiration require personal expertise. Social abilities are meanwhile empathized and emotionally competent. In essence, Robins stated that an individual's capacity in carrying out his job duties is based on intellectual abilities and physical abilities (intellectual and physical abilities). 
Attention to the human element (human nature) has subsequently created the interest to systematically design the human resource system (human system design) so that the public bureaucracy will increasingly function and behave appropriately to meet the expectations and aspirations of the public. In connection with this, Tjosvold \& Tjosvold (1991) have paid attention to the importance of developing skills, capabilities, temperament, mentality, and behavior alignment (human talents, skill abilities, traits, psyche, and behavioral adjustments) to compensate for display arrangement. Elegant structure and function that has been put forward. For this reason, a concept known as the soft human issue (quiet people issue) was introduced through production, coping, and adaptation efforts.

Coordination as an important aspect of management requires a human resource, which includes a mindset to solve a problem. The complexity of health problems requires integrated handling, all stakeholders related to the health sector need to work together, help each other, communicate with each other, work together and complement each other in accordance with their respective duties and functions (Tambunan et al, 2020).

Meanwhile, Yuwono (2001) underlines the need to foster the affective dimension and cognitive and psychomotor skills and experiences. The complete personal unity of policy behavior needs to be encouraged to balance expertise, skills, knowledge, and mental attitudes. The development of bureaucratic apparatus resources needs to synergistically integrate mental and spiritual aspects, mindset, professionalism, rationality, and skills to develop a patriot spirit.

Furthermore, in the discussion of Wilson (2017), its character complements the discussion data, which essentially highlights the need for the inclusion of elements of creativity, especially concerning the fulfillment of the dharma devotion to sublime tasks developed from the potential of individual intrinsic talents that complement the cognitive pathways. A person known by technical terms as creative, relevant skill. This humanistic psychological approach has succeeded in highlighting alternatives to personality behavior. The more specific and deeper Gartson (1983: 22) mandates that future human resource development interventions can touch deeply the dimensions of attitude, behavior, work ethic, and degree of service, which are called affirmative obligations that need to be managed proactively.

Furthermore, from the above discussion, Kondalkar (2020) has underlined the importance of a network of local public institutions by displaying the superior concepts (a network of local agencies in public affairs). The acquisition of the mentality of employees/officials with behavioral standards capable of bringing bureaucratic capabilities is not only proactive, cooperative, and adaptive, but it is even hoped that they will be able to act reactively and responsively so that public organizations can become role holders of state administrators essential with a choice of means in response to the dynamics of the dynamic and evolving political process.

With the above discussion, increase the expertise of local authorities to enhance public administration efficiency has been considered a determining factor for the success of implementing regional government activities. Such efforts can be carried out by selecting relevant dimensions and substance of normative elements, by taking into account the following concepts: the use of the authority which benefits the public interest which is sincere, open, disciplined, ethical, and has moral character; modern, professional thinking, and excellent performance and work culture. 


\subsection{The Role of Local Government in Achieving Good Governance}

Good governance was born in line with the concepts and terminology of democracy, civil society, people's participation, human rights, and sustainable community development (Nanda, 2006). The idea of governance in good governance is often confused with the concept of government. The government definition applies to a top authority administration organisation (State and government). The idea of governance, on the other hand, encompasses the government and the state and separate parties outside government and the state. The participating parties are also vast (Peters \& Pierre, 1998).

According to the World Bank definition, governance is "the way state power is used in managing economic and social resources for development and society" (Guhan, 1998). Meanwhile, UNDP describes this as "the exercise of political, economic, and administrative authority to manage a nation's affair at all levels" (Orr, 2002). Governance has three legs, based on this latter definition: Economic governance involves the process of decision-making which promotes wealth, poorness and quality of life. Political administration is a policy-making decision-making mechanism. Management is a decision mechanism implementation framework.

Therefore, the governance structures occupy three areas, namely the State, the private sector (private sector or business) and society (society). State contains government institutions and institutions in the public sector. The private sector entails private businesses working in various non-societal economies in such informal industries while the private sector impacts social, political and economic obligations and provides a businessand company-friendly climate. The society is made up of persons and classes, whether organized or not, who engage with formal and informal rules in a social, political and economic way. The association comprises NGO, technical organisation, SBO, Job association: staff organization; Professional association: ane, doctor, accountancy, law; Paguyuban and others Community of NGO and NGOs, professional organisations.

All three fields connect and perform their various duties. The state's position is to create a political and legal environment conducive to realizing sustainable human development. The private sector plays an essential role in development using a market approach. This strategy seeks to establish environments under which goods and services are created in order to create employment and profits for the population. In social, economic and political experiences, culture plays a constructive role, by inviting social classes to engage in economic, social and political activities.

From the various definitions above, They can be concluded that good governance is a condition that ensures equality, equality, cohesion, and balance of roles as well as the mutual control exercised by the three components, namely the government (government), the people (citizen) or civil society. And entrepreneurs (business) who are in the private sector. The three domains have the same and equal relationship system. This equality of degree significantly affects efforts to create good governance. Conversely, if the parity is not proven, there will be refraction where one of the domains involves and controls the other parts. The effort to balance the three components is the role that the public administration must play. Thus the science of public administration plays a role in studying and realizing the action program of democratic governance and running well. This balancing process is maintained by the public administration practitioner so that it does not stop at the sketch.

Strong governance or good governance demonstrate the society is able to manage its growth economies, structures and social and political capital and to establish stability, integration and well-being. The organization must have a significant role; power is no longer only in the rulers but also for the people or better known as democracy. Therefore 
the part of the people by the public administration is facilitated to be in a strong position in the constellation of this balance.

Similarly, the position of the private sector greatly promotes the establishment of a power balance in good governance. If the private sector's position can be above, public policymakers in the public administration system will be polluted and tempted to give private conglomerates or entrepreneurs lose access. This situation will create a collusive and nepotic government system.

If the state power exceeds the balance between the three domains, the government system will be centralistic and autocratic. This balance function is not easy because irregularities carried out by policy makers often tempt it. Policymakers usually work in the political sphere, while public administration is in the public bureaucracy. The tug of war between these two regions has long been the subject of a continuing dispute until now.

The idea of parallels between the three domains in good governance implies the importance of redefining these three institutions' roles and relationships in managing the available economic, political, and cultural resources in society. Proponents of this approach envision the emergence of a synergistic relationship between the three institutions to create a clean - responsive - responsible state, lively life of civil society, and a competitive and accountable market (business) life.

According to Tjokroamidjojo (2000), there are several indicators to determine good governance's success, including macroeconomic indicators, achieving sustainability milestones, quality of living and measures of recovery. The first three metrics include macroeconomic indicators, growth priorities and quality of life, indicate the success of good governance or good governance in general achieved by a country. In contrast, the recovery indicators show the success of a country when experiencing a crisis.

\section{Conclusion}

To support a more empowered bureaucratic apparatus, it is necessary to increase the competence of local government officials. Thus, theoretical knowledge is fundamental; with that knowledge, a person's reasoning ability is considered to be developed so that this intellectual ability can be clearly expressed; therefore, professionalism is needed in regional government administration activities that can combine theory with practice.

Good governance is the process of exercising state power in providing public good and service. It is called governance (government or governance), while the best practice is called "good governance." Three sectors, including government, private sector and culture, are interested in the introduction of good governance. Each portion has the same governance role. Good governance features include: commitment, integrity, compliance with the rules, openness, reaction, agreement-oriented, productivity and efficiency, equity, responsibility and a strategic viewpoint. To ensure good governance, those characteristics must be met. 


\section{References}

Angelia, N., et al. (2020). Analysis of Community Institution Empowerment as a Village Government Partner in the Participative Development Process. Budapest International Research and Critics Institute-Journal (BIRCI-Journal). P. 1352-1359.

Balachandran, S. (2004). Customer-Driven Services Management. SAGE Publications India.

Creswell, J. W. (2010). Research Design Pendekatan Kualitatif, Kuantitatif, dan Mixed. Yogyakarta: Pustaka Pelajar.

Darmalaksana, W. (2020). Metode Penelitian Kualitatif Studi Pustaka dan Studi Lapangan. Pre-Print Digital Library UIN Sunan Gunung Djati Bandung.

Denzin, N. K., \& Lincoln, Y. S. (2005). Introduction: The Discipline and Practice of Qualitative Research. APA PsycNet

Dwimawanti, I. (2004). Kualitas Pelayanan Publik. Jurnal Ilmu Administrasi dan Kebijakan Publik.

Dwiyanto, A. (2021). Reformasi Birokrasi Publik di Indonesia. Yogyakarta: UGM Press.

Fitzpatrick, R. (1994). Competence at Work: Models for Superior Performance. Personnel Psychology, 47(2), 448.

Guhan, S. (1998). World Bank on Governance: A Critique. Economic and Political Weekly, 185-190.

Hardjati, S. (2017). Model Alternatif Pengukuran Kinerja Aparatur Di Era Otonomi Daerah. Dinamika Governance: Jurnal Ilmu Administrasi Negara, 7(2).

Haris, S. (Ed.). (2005). Desentralisasi dan Otonomi Daerah: Desentralisasi, Demokratisasi \& Akuntabilitas Pemerintahan Daerah. Yayasan Obor Indonesia.

Hoffmann, T. (1999). The Meanings of Competency. Journal of European Industrial Training.

Holtzappel, C. J., \& Ramstedt, M. (Eds.). (2009). Decentralization and Regional Autonomy in Indonesia: Implementation and Challenges. Institute of Southeast Asian Studies.

Komara, E. (2019). Kompetensi Profesional Pegawai ASN (Aparatur Sipil Negara) di Indonesia. MIMBAR PENDIDIKAN, 4(1), 73-84.

Kondalkar, V. G. (2020). Organizational Behaviour. New Age.

Kusuma, H. (2016). Desentralisasi Fiskal dan Pertumbuhan Ekonomi di Indonesia. Desentralisasi Fiskal dan Pertumbuhan Ekonomi di Indonesia, 9(1), 1-11.

Mariana, D. (2006). Reformasi Birokrasi Pemerintah Pasca Orde Baru. Sosiohumaniora, $8(3), 240$.

McClelland, D. C. (1973). Testing for Competence Rather than For" Intelligence.". American psychologist, 28(1), 1.

Minardi, A. (2019). Politik Reformasi Birokrasi. Pendayagunaan Aparatur Negara, 2, 4-9.

Moonti, R. M. (2019). Regional Autonomy in Realizing Good Governance. Substantive Justice International Journal of Law, 2(1), 43-53.

Muliawaty, L., \& Hendryawan, S. (2020). Peranan E-Government dalam Pelayanan Publik (Studi Kasus: Mal Pelayanan Publik Kabupaten Sumedang). Kebijakan: Jurnal Ilmu Administrasi, 11(2), 45-57.

Nanda, V. P. (2006). The "Good Governance" Concept Revisited. The ANNALS of the American academy of political and social science, 603(1), 269-283.

Needham, C. E. (2006). Customer Care and The Public Service Ethos. Public Administration, 84(4), 845-860. 
Oja, H. (2017). Dinamika Good Local Governance Dalam Kerangka Pelayanan Publik Di Era Otonomi Daerah. Societas: Jurnal Ilmu Administrasi dan Sosial, 6(1), 1-16.

Orr, R. (2002). Governing When Chaos Rules: Enhancing Governance and Participation. Washington Quarterly, 25(4), 139-152.

Perry, J. L., \& Rainey, H. G. (1988). The Public-Private Distinction in Organization Theory: A Critique and Research Strategy. Academy of Management Review, 13(2), 182-201.

Peters, B. G., \& Pierre, J. (1998). Governance Without Government? Rethinking Public Administration. Journal of Public Administration Research and Theory, 8(2), 223-243.

Rahmadana, M. F., Mawati, A. T., Siagian, N., Perangin-angin, M. A., Refelino, J., Tojiri, M. Y., ... \& Bahri, S. (2020). Pelayanan Publik. Yayasan Kita Menulis.

Rohayatin, T., Warsito, T., Pribadi, U., Nurmandi, A., \& Kumorotmo, W. (2017). Faktor Penyebab Belum Optimalnya Kualitas Penyelenggaraan Pelayanan Publik dalam Birokrasi Pemerintahan. Jurnal Caraka Prabu, 1(01), 22-36.

Rosdiana, R. (2019). Peranan Pemerintah dalam Sistem Administrasi Negara. Meraja Journal, 2(2), 109-117.

Sandberg, J. (2000). Understanding Human Competence at Work: An Interpretative Approach. Academy of Management Journal, 43(1), 9-25.

Saputra, D. P., \& Kurniawansyah, F. (2020). Tantangan BKD Kota Malang Dalam Menyiapkan ASN Di Era Digital. Prosiding Simposium Nasional"Tantangan Penyelenggaraan Pemerintahan di Era Revolusi Indusri 4. O", 1320-1350.

Setiyono, B. (2012). Birokrasi Dalam Perspektif "Politik \& Administrasi" (Vol. 1). Nuansa.

Sternberg, R. J., \& Kaufman, J. C. (1998). Human Abilities. Annual review of psychology, 49(1), 479-502.

Sumarsono, H. (2009). Analisis Kemandirian Otonomi Daerah: Kasus Kota Malang (19992004). Jurnal Ekonomi dan Studi Pembangunan, 1(1).

Sutrisna, I. W. (2020). Implementasi Kebijakan Desentralisasi Menuju Masyarakat Mandiri Dan Sejahtera. Jurnal Ilmiah Cakrawarti, 3(1), 10-19.

Tambunan, M.S., et al. (2020). HKBP HIV-AIDS Committee Balige Coordination with the Regional Government HIV-AIDS Handling Program in Toba Samosir Regency 2018. Budapest International Research and Critics Institute-Journal (BIRCI-Journal). P. 1435-1442.

Tahir, A. (2014). Kebijakan Publik dan Transparansi Penyelenggaraan Pemerintahan Daerah. Bandung: Alfabeta.

Tjokroamidjojo, B. (2000). Good governance. Paradigma Baru Manajemen Pembangunan. Jakarta: UI press.

Tjosvold, D., \& Tjosvold, M. M. (1991). Leading The Team Organization: How to Create An Enduring Competitive Advantage. Lexington Books.

Von Mises, L., \& Morris, R. (1944). Bureaucracy (p. 47). New Haven: Yale University Press.

Wahid, A. A. (2017). Reformasi Pelayanan Publik di Indonesia. Jurnal TAPIs, 14(1), 1-10.

Wibowo, A. P., \& Handayani, N. (2017). Faktor-Faktor Yang Mempengaruhi Kinerja Aparat Pemerintah Daerah Kota Surabaya. Jurnal Ilmu Dan Riset Akuntansi (JIRA), 6(7).

Wilson, F. M. (2017). Organizational Behaviour and Gender. Routledge.

Woodruffe, C. (1993). What Is Meant By A Competency?. Leadership \& Organization Development Journal.

Yuwono, T. (2001). Manajemen Otonomi Daerah: Membangun Daerah Berdasar Paradigma Baru. CLoGAPPS, Diponegoro University. 